\title{
Removing nitrogenous compounds from landfill leachate using electrochemical techniques
}

\author{
Nadeeshani Nanayakkara ${ }^{\dagger}$, Asanga Koralage, Charuka Meegoda, Supun Kariyawasam \\ Department of Civil Engineering, Faculty of Engineering, University of Peradeniya, Kandy 20400, Sri Lanka
}

\begin{abstract}
In this research, applicability of electrochemical technology in removing nitrogenous compounds from solid waste landfill leachate was examined. Novel cathode material was developed at laboratory by introducing a $\mathrm{Cu}$ layer on $\mathrm{Al}$ substrate $(\mathrm{Cu} / \mathrm{Al})$. $\mathrm{Al}$ and mild steel (MS) anodes were investigated for the efficiency in removing nitrogenous compounds from actual leachate samples collected from two open dump sites. Al anode showed better performances due to the effect of better electrocoagulation at $\mathrm{Al}$ surface compared to that at MS anode surface. Efficiency studies were carried out at a current density of $20 \mathrm{~mA} / \mathrm{cm}^{2}$ and at reaction duration of $6 \mathrm{~h}$. Efficiency of removing nitrate-N using Al anode and developed $\mathrm{Cu} / \mathrm{Al}$ cathode was around $90 \%$. However, for raw leachate, total nitrogen (TN) removal efficiency was only around $30 \%$. This is due to low ammonium-N removal as a result of low oxidation ability of Al. In addition to the removal of nitrogenous compounds, reactor showed about 30\% removal of total organic carbon. Subsequently, raw leachate was diluted four times, to simulate pre-treated leachate The diluted leachate was treated and around $88 \%$ removal of TN was achieved. Therefore, it can be said that the reactor would be good as a secondary or tertiary treatment step in a leachate treatment plant.
\end{abstract}

Keywords: Electrochemical technology, Electrocoagulation, Electrodes, Leachate, Nitrogenous compounds

\section{Introduction}

Sanitary landfills are used worldwide to dispose municipal solid waste, although it is not the most economical and environmental friendly method [1]. The sanitary landfills should be carefully designed and maintained to minimize the release of contaminants to the environment. While these sites are constructed to dispose waste by burial in land, open dump sites are also use in some countries. Generation of leachate is one of the major problems which occur whether the dump site is open or buried one [2].

Leachate is known as a highly polluted liquid, which comes out from sanitary landfills, when water passing through it. It contains a wide range of chemical compounds such as $\mathrm{NO}_{3}^{-}, \mathrm{NO}_{2}^{-}$, $\mathrm{PO}_{4}{ }^{3-}, \mathrm{NH}_{4}{ }^{+}$, heavy metals and oxygen demanding substances. Characteristics of leachate may depend on several factors such as temperature and other climatic factors, degree of wetness, age of landfill and type of waste [3]. Leachate pollutes both water and soil [4] and this would in turn affect the human health. As such, generation of leachate from landfills should control, collect properly and treat before releasing to the environment, wherever possible.

Nitrogen compounds including nitrate $\left(\mathrm{NO}_{3}{ }^{-}\right)$, nitrite $\left(\mathrm{NO}_{2}{ }^{-}\right)$ and ammonium $\left(\mathrm{NH}_{4}^{+}\right)$can be found in leachate. Total nitrogen (TN) content of leachate can be in the range of $2.6-945 \mathrm{mg} / \mathrm{L}$ and the upper limit can be even as high as $1,416 \mathrm{mg} / \mathrm{L} \mathrm{[5].}$ Nitrogenous compounds, mainly the compounds which contain inorganic nitrogen, create environmental impacts such as eutrophication, acidification of surface water, toxicity to aquatic animals, and increased algal blooms [6]. Nitrate and nitrite are known as primary water pollutants and regulated in drinking water standards such as the United States Environmental Protection Agency (USEPA) national primary drinking water regulations and World Health Organization (WHO) drinking water quality guidelines. High nitrate levels in drinking water can cause methemoglobanemia in infants and stomach cancer in adults [7].

WHO specifies that the ammonia level occurs in drinking-water is at concentrations well below those of health concern. However, ammonia can cause taste and odor problems when its concentrations are above 35 and $1.5 \mathrm{mg} / \mathrm{L}$, respectively [7]. Amount of the ammonia found in leachate are generally higher than the
This is an Open Access article distributed under the terms of the Creative Commons Attribution Non-Commercial License (http://creativecommons.org/licenses/by-nc/3.0/) which permits unrestricted non-commercial use, distribution, and reproduction in any medium, provided the original work is properly cited.
Received March 21, 2018 Accepted September 4, 2018

${ }^{\dagger}$ Corresponding author

Email: kgnn@pdn.ac.lk

Tel: +94-81-2393574 Fax: +94-81-2388158

Copyright (C) 2019 Korean Society of Environmental Engineers 
WHO limits [2]. For example, the ammonia level can be even above $400 \mathrm{mg} / \mathrm{L}$ in stabilized landfill leachate [8]. If discharged in to a water body, such high concentrations of ammonia may create pollution issues in receiving environments. Therefore, leachate should be treated before releasing to the environment.

Biological, physical, chemical and physiochemical methods are available for removing nitrogenous compounds from leachate. While consumes low energy, biological treatment methods need long retention times and more space [9]. The physiochemical methods such as ammonia stripping, coagulation, flocculation, precipitation and adsorption can be expensive, mainly due to high cost for chemicals. Membrane technology is also another effective treatment method, but it is expensive and generates concentrated brine solutions [1,9].

Electrochemical treatment method is a technology which can be used in removing nitrogenous compounds from contaminated water. Electrochemical cell consists of two electrodes which are known as anode and cathode. Anode contributes to the oxidation process and cathode contributes to the reduction process. Electrochemical methods occupy small area and it needs relatively low investment cost. However, to be energy efficient, the electrolyte should have sufficient conductivity. In addition, developing the suitable electrode materials increases the efficiency of the system [10].

Electrochemical removal of nitrogenous compounds can be achieved through electrochemical reduction combined with electrochemical oxidation. Eq. (1)-(3) show the important reactions involved in electrochemical removal of nitrogenous compounds.

Reactions at cathode:

$$
\begin{gathered}
\left.\mathrm{NO}_{3}^{-} \stackrel{\text { Reduction }}{\longrightarrow} \text { By-products (eg. } \mathrm{NH}_{4}^{+}, \mathrm{NO}_{2}^{-}\right)+\mathrm{N}_{2} \\
\mathrm{NO}_{2}^{-} \stackrel{\text { Reduction }}{\longrightarrow} \text { By-products }\left(\text { eg. } \mathrm{NH}_{4}^{+}\right)+\mathrm{N}_{2}
\end{gathered}
$$

Reactions at anode:

$$
\text { By-products and } \mathrm{NH}_{4}^{+} \stackrel{\text { Oxidation }}{\longrightarrow}+\mathrm{NO}_{3}^{-}
$$

As shown in Eq. (1)-(3), both cathode and anode are important in removing nitrogenous compounds. Although the nitrate and nitrite reduction occurs at cathode, the reduction by-products should be effectively converted to $\mathrm{N}_{2}$ or $\mathrm{NO}_{3}^{-}$at anode. While $\mathrm{N}_{2}$ leaves the system, $\mathrm{NO}_{3}{ }^{-}$reduced back to $\mathrm{N}_{2}$ and by-products. These reactions occur in cyclic nature, providing avenues to remove nitrogenous compounds from polluted water. In addition, the presence of chloride ions in electrolyte would enhance performance since electrochemically generated chlorine acts favourably in oxidizing $\mathrm{NH}_{4}{ }^{+}$[11]. Moreover, through careful selection of electrodes, simultaneous removal of other co-existing pollutants also would be possible (e.g., organics contaminants, micro-organisms) [12].

Electrochemical nitrate removal has been studied and reported in literature [7, 13-17]. Cathode materials such as $\mathrm{Ni}, \mathrm{Fe}, \mathrm{Rh}$, $\mathrm{Pb}$, and $\mathrm{Cu}$ has been researched in literature, and among them, $\mathrm{Cu}$ has been identified as one of the best cathodes in electro- chemical reduction of nitrate [18-21]. About 99\% removal of nitrate from groundwater within $2 \mathrm{~h}$ of reaction time has reported in literature using laboratory developed $\mathrm{Cu} / \mathrm{Ti}$ cathode and $\mathrm{IrO}_{2} / \mathrm{Ti}$ anode [7]. Conductivity of groundwater in above study was ranged from about $350 \mu \mathrm{s} \mathrm{cm}^{-1}-1,300 \mu \mathrm{s} \mathrm{cm}^{-1}$, while the $\mathrm{NO}_{3}^{-}$concentration was around $175 \mathrm{mg} / \mathrm{L}$. Using electrochemical technology, near complete removal of ammonium from solutions at the presence of chloride ion is reported in literature [22]. More than 95\% of ammonia removal from treated municipal wastewater, which were collected after aerobic or anaerobic treatment showed the suitability of technology as a post-treatment nitrate removal step [23].

Although the electrochemical techniques has been investigated in literature for removing nitrogenous compounds including nitrate and ammonium, studies on application of the technology to remove nitrogenous compounds from leachate are limited. Since leachate is a complex pollutant which contains varying amounts of different pollutants, removing nitrogenous compounds of leachate can be a challenging task. In addition, selection of low cost electrodes for cathode and anode is a key factor in actual application, especially in developing world. As such, this study was mainly targeted on removing nitrogenous compounds from leachate using low cost electrodes as cathode and anode. Considering additional benefits at the point of engineering application, simultaneous removal of total organic carbon (TOC) also investigated.

\section{Materials and Methods}

\subsection{Materials}

EDTA, formaldehyde, copper nitrate and sulfuric acid were purchased from Sigma-Aldrich. Sodium hydroxide (96\%), hydrogen peroxide, sodium sulfate (anhydrous) (99\%), and $\mathrm{K}_{2} \mathrm{SO}_{4}$ were purchased from Meron Cochin. Nitrite power pillows and nitrate power pillows were used for nitrite and nitrate detection experiments respectively while Nessler regent, mineral stabilizer and polyvinyl alcohol dispersing agent were used to detect ammonia present in leachate which were from HACH. All aqueous solutions were prepared by using deionized water and all chemicals were analytical grade.

\subsection{Methods}

\subsubsection{Electrochemical reactor set-up}

Fig. 1 shows a schematic diagram of the electrochemical cell, which was used to remove nitrogenous compounds and TOC from landfill leachate. A two electrode batch reactor cell with a volume of $50 \mathrm{~mL}$ was used as the electrochemical reactor. A potentiostat-galvanostat (Metrohm Autolab PGSTAT 128N) was employed to provide direct current to the reactor. Current was kept at pre-determined required value for necessary reaction duration. Reactions were carried out at room temperature.

The reactor cell shown in Fig. 1 has two electrodes, namely, cathode and the anode. Copper coated Aluminum (Cu/Al) electrodes were prepared at the laboratory using electroless plating and used as the cathode of the electrochemical reactor. In electroless plating, a reducing agent is employed in coating bath to reduce 


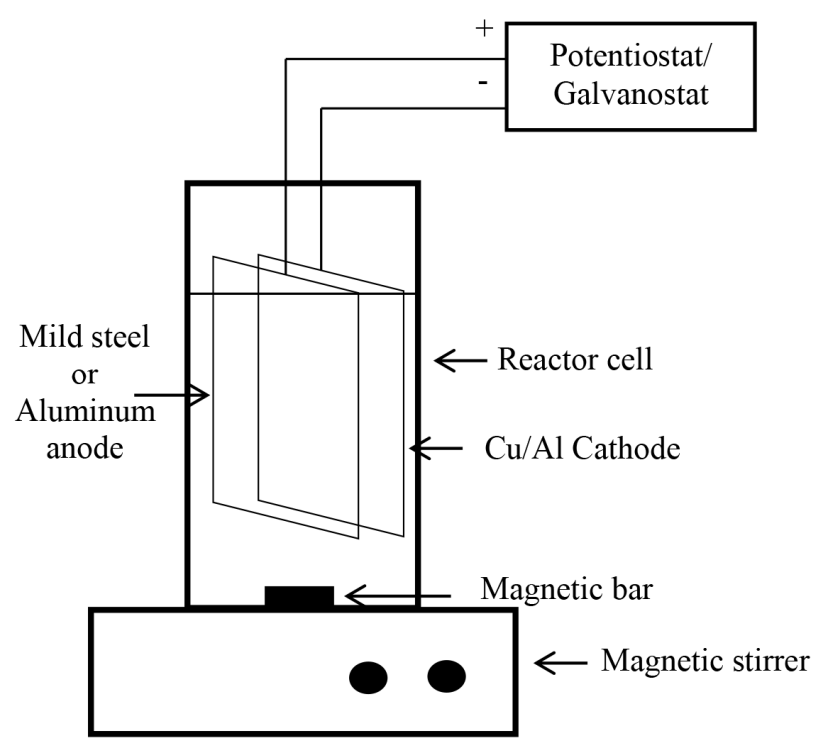

Fig. 1. Schematic diagram of the electrochemical cell.

required metal ion on the surface of the substrate material. For coating the cathode, $\mathrm{Al}$ sheet was shaped into electrodes of $1 \mathrm{~cm}$ $\times 1 \mathrm{~cm}$. $5 \%$ aqueous sodium hydroxide solution at $60^{\circ} \mathrm{C}$ was used for the removal of grease. Next, the substrate was etched using 5\% sulphuric acid and 5\% hydrogen peroxide. The operational temperature was maintained at nearly $60^{\circ} \mathrm{C}$. Then the substrate was neutralized using $5 \%$ sodium hydroxide solution in order to remove etchants that might have remained on the substrate from the previous step. Initial weight of these substrate materials were measured using an electronic scale. The dimensions of the electrodes were measured and their geometrical surface area was calculated. Electroless plating requires a plating bath where the electrode is immersed. In this study EDTA bath was used as the plating bath. EDTA solutions with different concentrations were prepared and sodium hydroxide was added to the solution. The solution was stirred until EDTA completely dissolved. Then $0.05 \mathrm{M}$ cupric nitrate was added to the solution making sure that cupric nitrate is fully dissolved. Solution $\mathrm{pH}$ was adjusted as required. Formaldehyde solutions of varied concentrations were used as the reducing agent. Plating was carried out at room temperature, which was around $27^{\circ} \mathrm{C}$. The best cathode was selected and subsequently used as the cathode in the electrochemical reactor cell.

Mild steel (MS) or $\mathrm{Al}(1 \mathrm{~cm} \times 1 \mathrm{~cm})$ was used as anode, considering the low cost of these anode materials.

\subsubsection{Electrode characterization}

Electrochemical analyses of developed electrodes were carried out using the potentiostat-galvanostat (Metrohm Autolab PGSTAT $128 \mathrm{~N}$ ) equipment. Open circuit potential technique was used in order to analyze the electrode stability. For all these analysis, three electrode systems were used with a $\mathrm{Ag} / \mathrm{AgCl}$ electrode as the reference electrode (RE). Electrolyte type and other necessary experimental parameters were changed as required and those details are given with relevant figures/ illustrations.
Scanning electron microscopy (SEM) was conducted on the coated samples by scanning electron microscope Zeiss Evo LS15. The surface structures of the coated samples were compared with substrate material prior to coating. Surface chemical composition was detected using Energy Dispersive X-ray (EDX) analyzer coupled with the Zeiss Evo LS15 scanning electron microscope.

\subsubsection{Leachate collection and characterization}

Leachate from Gohagoda ( $7^{0} 19^{\prime}$, E 80 $37^{\prime}$ ) and Udapalatha ( $7^{0} 09^{\prime}, \mathrm{E} 80^{\circ} 35^{\prime}$ ) landfill sites were collected and characterized before using the samples for reactor efficiency analysis. Gohagoda landfill is an active landfill while Udapalatha landfill is an abandoned landfill. DR/2010 HACH spectrophotometer was used for detecting $\mathrm{NH}_{3}, \mathrm{NO}_{3}^{-}$and $\mathrm{NO}_{2}^{-}$in leachate before and after treatment. Total Carbon Analyzer (Shemadzu TOC-L CSH 638-91111-48) was used to find the total carbon (TC), total inorganic carbon (IC), TOC and TN amount present in the leachate samples before and after treatments. $\mathrm{pH}$ and electrical conductivity were measured using appropriate probes.

\section{Results and Discussion}

\subsection{Cathode Material Development}

Electroless plating was carried out to coat $\mathrm{Cu}$ on $\mathrm{Al}$ substrates at varying coating conditions. The coating layers were analyzed using SEM and EDX technologies. SEM images of the electrodes and results of the EDX analysis are shown in Fig. 2 and Table 1, respectively. Fig. 2 and Table 1 clearly reveal that the electroless coating technique has successfully introduced $\mathrm{Cu}$ on to the $\mathrm{Al}$ plate electrodes. Table 1 shows that the coated $\mathrm{Cu}$ percentage is almost the same irrespective of the concentration of the reducing agent, i.e., $\mathrm{HCOH}$. In addition, Fig. 2 shows that the surfaces of developed $\mathrm{Cu} / \mathrm{Al}$ cathodes may contain higher amount of pores compared to the uncoated $\mathrm{Cu}$ and $\mathrm{Al}$ cathodes. The laboratory developed cathode surfaces contain cracks and grains developed on them as a result of $\mathrm{Cu}$ deposition. These structural changes would be important to get higher electrochemically active surface area on electrodes. The electrochemically active surface areas of the electrodes can be indirectly compared through cyclic voltametric (CV) analysis. Therefore, CV analysis was carried out using $\mathrm{Cu} / \mathrm{Al}$ electrodes and $\mathrm{Cu}$ plate as working electrode in a three electrode cell setup. Fig. 3 shows the obtained current vs. potential and charge vs. potential curves. It can be seen that the uncoated $\mathrm{Cu}$ electrode shows the highest charge compared to the other three electrodes. Since charge is an indirect measure of electrochemical active surface area [7], it can be said that the uncoated electrode contains a higher electrochemically active surface area compared to other three electrodes. Although this finding is contradictory to the simple visual observation of SEM images, electrochemical analysis would be more accurate than visual observation. Thus, it is believed that the electrochemically active surface area is higher in uncoated $\mathrm{Cu}$ plate compared to the three $\mathrm{Cu} / \mathrm{Al}$ coated electrodes.

Since cathode plays a crucial role in denitrification, four electrodes were used in removing nitrate from a synthetic nitrate solution. 

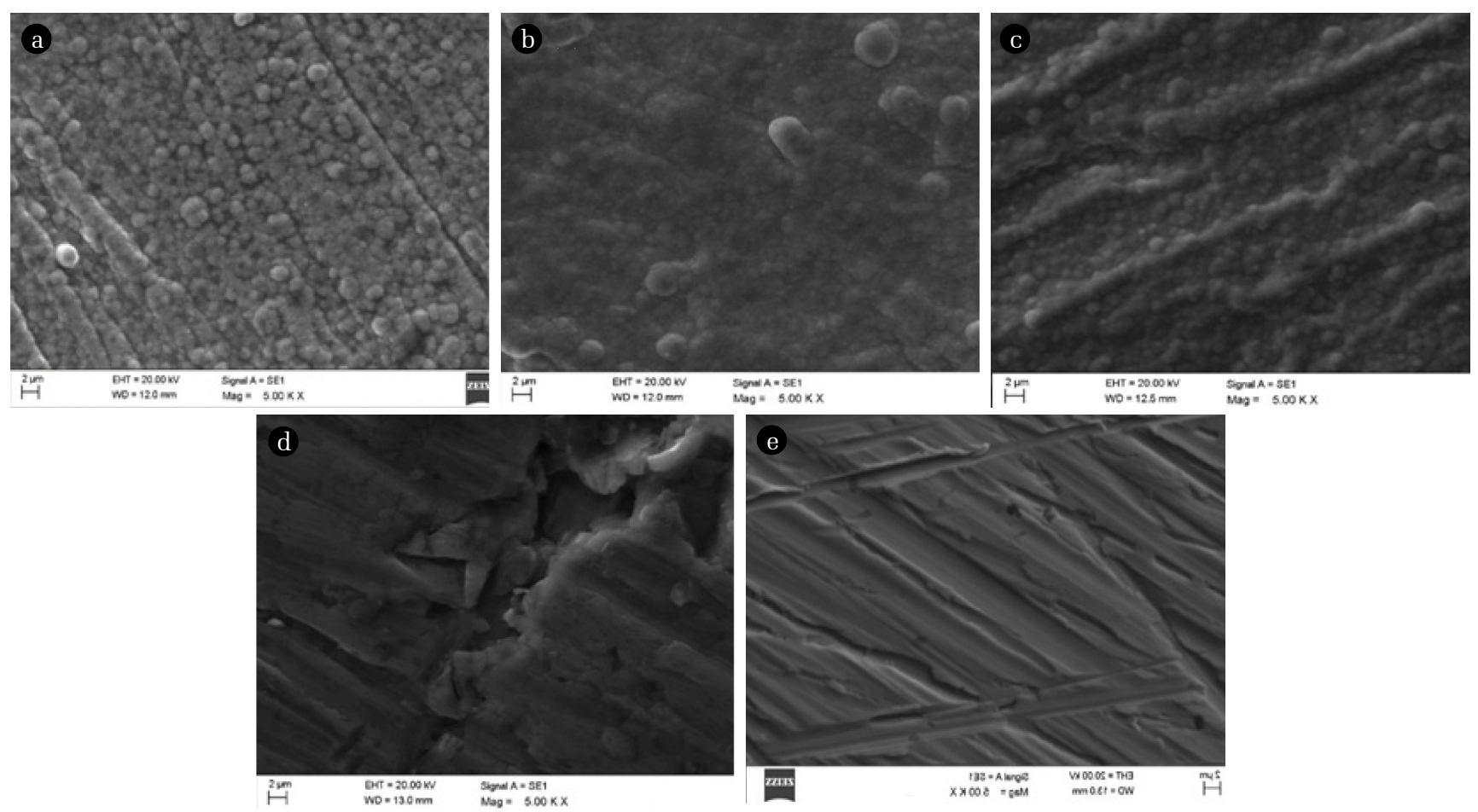

Fig. 2. SEM images of cathodes. (a) $\mathrm{Cu} / \mathrm{Al}\left(0.2 \mathrm{M} \mathrm{HCOH}, 0.1 \mathrm{M} \mathrm{CuSO}_{4}, 0.05 \mathrm{M}\right.$ EDTA) (b) $\mathrm{Cu} / \mathrm{Al}(0.1 \mathrm{M} \mathrm{HCOH}, 0.1 \mathrm{M} \mathrm{CuSO}, 0.05 \mathrm{M}$ EDTA) (c) $\mathrm{Cu} / \mathrm{Al}\left(0.3 \mathrm{M} \mathrm{HCOH}, 0.1 \mathrm{M} \mathrm{CuSO}_{4}, 0.05 \mathrm{M} \mathrm{EDTA}\right)$ (d) Uncoated Al plate (e) Uncoated Cu plate. Coating bath pH was adjusted to 12 .

Table 1. Weight Percentages and Atomic Percentages of Elements Present on Cathodes: EDX

\begin{tabular}{|c|c|c|c|c|c|c|c|c|}
\hline \multirow{4}{*}{ Cathode } & \multicolumn{8}{|c|}{ Elements } \\
\hline & Al & $\mathrm{Cu}$ & $\mathbf{O}$ & C & Fe & Ag & Si & Zn \\
\hline & Weight \% & Weight \% & Weight \% & Weight \% & Weight \% & Weight \% & Weight \% & Weight \% \\
\hline & Atomic \% & Atomic \% & Atomic \% & Atomic \% & Atomic \% & Atomic \% & Atomic \% & Atomic $\%$ \\
\hline \multirow{2}{*}{$\begin{array}{l}\text { (a) } \mathrm{Cu} / \mathrm{Al}(0.2 \mathrm{M} \mathrm{HCOH}, 0.1 \mathrm{M} \\
\left.\mathrm{CuSO}_{4}, 0.05 \mathrm{M} \text { EDTA }\right)\end{array}$} & 0.48 & 68.80 & 27.04 & 3.34 & - & - & 0.34 & - \\
\hline & 0.58 & 35.15 & 54.85 & 9.03 & - & - & 0.39 & - \\
\hline \multirow{2}{*}{$\begin{array}{c}\text { (b) } \mathrm{Cu} / \mathrm{Al}(0.1 \mathrm{M} \mathrm{HCOH}, 0.1 \mathrm{M} \\
\left.\mathrm{CuSO}_{4}, 0.05 \mathrm{M} \text { EDTA }\right)\end{array}$} & 0.22 & 71.12 & 25.78 & 2.88 & - & - & - & - \\
\hline & 0.27 & 35.57 & 54.10 & 8.06 & - & - & - & - \\
\hline \multirow{2}{*}{$\begin{array}{l}\text { (c) } \mathrm{Cu} / \mathrm{Al}(0.3 \mathrm{M} \mathrm{HCOH}, 0.1 \mathrm{M} \\
\left.\mathrm{CuSO}_{4}, 0.05 \mathrm{M} \text { EDTA }\right)\end{array}$} & 0.42 & 67.43 & 27.95 & 3.80 & - & - & 0.41 & - \\
\hline & 0.49 & 33.64 & 55.37 & 10.04 & - & - & 0.46 & - \\
\hline \multirow{2}{*}{ (d) Uncoated Al plate } & 47.09 & - & 49.11 & 2.57 & 0.11 & 0.87 & 0.25 & - \\
\hline & 34.57 & - & 60.81 & 4.24 & 0.04 & 0.16 & 0.17 & - \\
\hline \multirow{2}{*}{ (e) Uncoated $\mathrm{Cu}$ plate } & - & 70.23 & 23.28 & 1.66 & - & - & - & 4.83 \\
\hline & - & 39.86 & 52.49 & 4.98 & - & - & - & 2.66 \\
\hline
\end{tabular}

The reason behind conducting this investigation is only to compare the performance of the four cathodes under consideration. Titanium anode was used in this investigation in order to minimize the involvement of anode in electrocoagulation; it should be noted that both $\mathrm{Al}$ and MS anodes would contribute in removing nitrate, due to their ability in developing coagulants during reaction. Results of this analysis are reported in Table 2.

Table 2 shows that, although the electrochemically active sur- face area is large, the removal efficiency of pure $\mathrm{Cu}$ cathode is lower than that of the developed electrodes. This finding can be explained as follows. As shown in SEM images (Fig. 2), the developed electrodes contain defects on the surface. As such, during large reaction durations, migration of electrolyte solution in to the deposited $\mathrm{Cu}$ layer may occur. The migrated electrolyte would form minute electrolysis cells within the electrode coating layer. Thus, there is a possibility of formation of anodic sites 

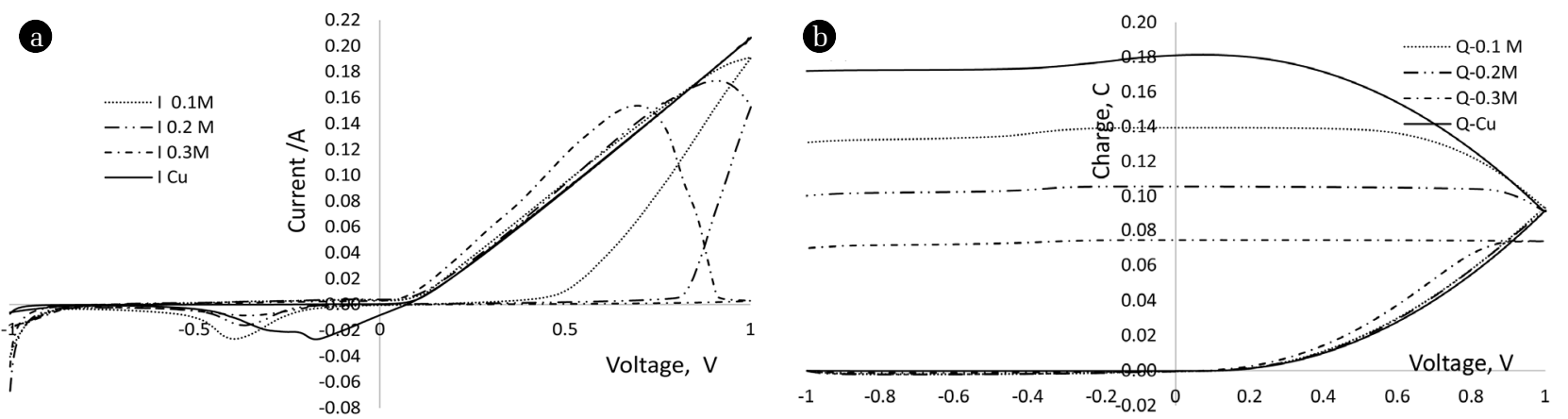

Fig. 3. Cyclic voltamettry analysis of $\mathrm{Cu} / \mathrm{Al}$ electrodes (coated with $0.1 \mathrm{M}, 0.2 \mathrm{M}$, and $0.3 \mathrm{MHCOH}$ ) and uncoated Cu electrode. (a) Variation of current with potential (voltage). (b) Variation of charge with potential (voltage). Experimental conditions- Electrolyte: $0.5 \mathrm{~mol} \mathrm{dm}^{-3} \mathrm{~K}_{2} \mathrm{SO}_{4}$ solution, Scan voltage range: $-1 \mathrm{~V}$ to $1 \mathrm{~V}$, Scan rate: $0.01 \mathrm{Vs}^{-1}$. Geometrical areas of all four electrodes were the same.

Table 2. Nitrate Removal Efficiency of Developed and Pure Cu Cathodes (Experimental conditions: Ti anode, $0.02 \mathrm{~A} / \mathrm{cm}^{2}$ current density, 90 min reaction period)

\begin{tabular}{lccc}
\hline Electrode & Initial nitrate concentration (ppm) & Final nitrate concentration (ppm) & Nitrate removal percentage \\
\hline Pure $\mathrm{Cu}$ & 15 & 4 & $73.3 \%$ \\
$\mathrm{Cu} / \mathrm{Al}$ cathode $(0.1 \mathrm{M} \mathrm{HCOH})$ & 15 & Below the detection limit & $>98 \%$ \\
$\mathrm{Cu} / \mathrm{Al}$ cathode $(0.2 \mathrm{M} \mathrm{HCOH})$ & 15 & (Detection limit: $0.3 \mathrm{mg} / \mathrm{L})$ & $>98 \%$ \\
$\mathrm{Cu} / \mathrm{Al}$ cathode $(0.3 \mathrm{M} \mathrm{HCOH})$ & 15 & & $>98 \%$ \\
\hline
\end{tabular}

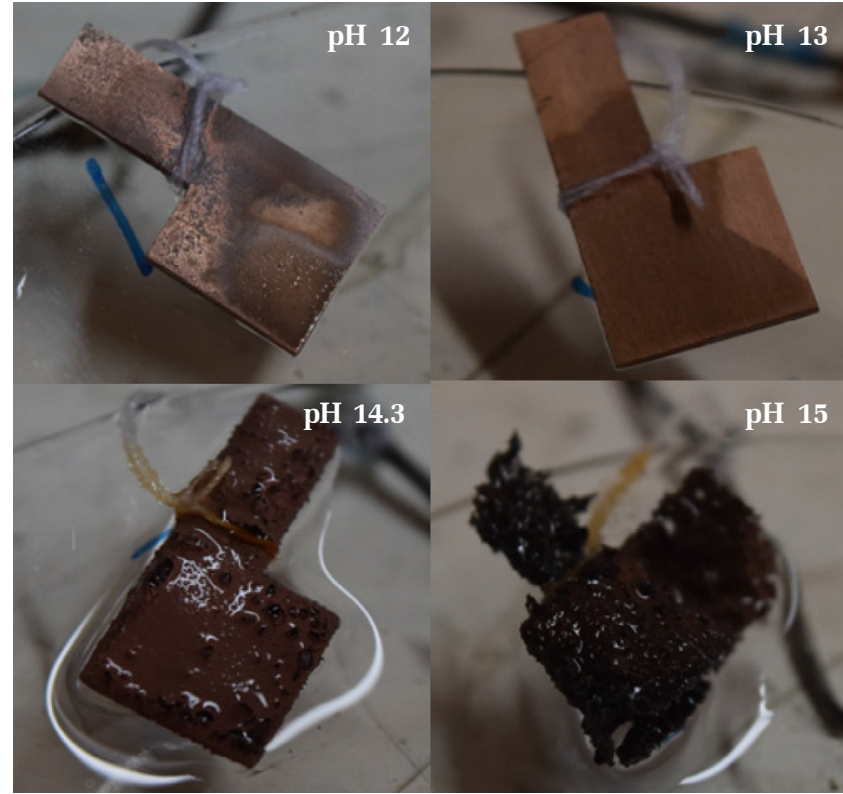

Fig. 4. Surface of the $\mathrm{Al} / \mathrm{Cu}$ cathodes developed at different plating bath $\mathrm{pH}$ values. Pictures were taken after $24 \mathrm{~h}$ of dipping.

inside the deposited $\mathrm{Cu}$ layers [7]. Since the $\mathrm{Cu}$ layers are deposited on $\mathrm{Al}$ substrates, electrocoagulation process may occur during the reaction due to the anodic reaction at $\mathrm{Al}$ surface. The anodically generated $\mathrm{Al}^{3+}$ ions support the electrocoagulation [24, 25]. In literature, it has been reported that electrocoagulation process does support the nitrate removal [26].

Based on above results, $\mathrm{Cu} / \mathrm{Al}$ cathode coated with $0.1 \mathrm{M} \mathrm{HCOH}$ was selected for further investigations. Subsequently, few more experiments were carried out to identify the coating bath $\mathrm{pH}$ vs. coating morphology/ quality. Fig. 4 shows the surface morphology of the cathodes developed at different $\mathrm{pH}$ (all the other plating bath conditions were kept the same). Based on the surface morphology (visual observation alone), it can be said that the coating developed at $\mathrm{pH} 13$ is better than the other coating layers.

\subsection{Removing Nitrogenous Compounds from Leachate}

\subsubsection{Efficiency studies with actual leachate samples}

Characteristics of leachate from two different landfills in Sri Lanka are shown in Table 3. Initially, landfill leachate sample which was collected from Gohagoda landfill site was treated in electrochemical reactor with $\mathrm{Cu} / \mathrm{Al}$ cathode. Either $\mathrm{Al}$ or $\mathrm{MS}$ was used as the anode of the reactor. TN removal as well as TOC removal was studied, since the simultaneous removal of TOC would be an added advantage. Results of this investigation are shown in Table 4.

As shown in Table 4, electrochemical reactor has the possibility of simultaneously removing TN as well as TOC. This study is beneficial since it provides additional details about removing major co-existing pollutants. It can be seen that the $\mathrm{Al}$ anode together with $\mathrm{Cu} / \mathrm{Al}$ cathode gives better performance in removing $\mathrm{TN}$. However, when it comes to removing TOC, MS anode gives better performance.

$\mathrm{Al}$ anode is good in electrocoagulation process and it has been reported that the electrocoagulation supports denitrification through removing nitrate from the polluted water [26]. Open circuit potential (OCP) study shows OCP of $\mathrm{Al}$ and MS electrodes as $-1.175 \mathrm{~V}$ and $-0.96 \mathrm{~V}$, respectively. That means, Al anode shows 
Table 3. Characteristics of Gohagoda and Udapalatha Leachate

\begin{tabular}{lccc}
\hline \multirow{2}{*}{ Parameter } & \multirow{2}{*}{ Unit } & \multicolumn{2}{c}{ Value } \\
\cline { 3 - 4 } & & Gohagoda & Udapalatha \\
\hline $\mathrm{pH}$ & $\mathrm{mS}$ & 31.36 & 7.11 \\
$\mathrm{EC}$ & $\mathrm{mg} / \mathrm{L}$ & 560 & 210.9 \\
Ammonia-N & $\mathrm{mg} / \mathrm{L}$ & 10 & 31.7 \\
Nitrate-N & $\mathrm{mg} / \mathrm{L}$ & Undetectable & Undetectable \\
Nitrite-N & $\mathrm{mg} / \mathrm{L}$ & 1,305 & 540.8 \\
Total carbon (TC) & $\mathrm{mg} / \mathrm{L}$ & 129.6 & 367 \\
Total inorganic carbon (IC) & $\mathrm{mg} / \mathrm{L}$ & $1,175.4$ & 173.9 \\
Total organic carbon (TOC) & $\mathrm{mg} / \mathrm{L}$ & 577.8 & 245.3 \\
Total nitrogen (TN) & & &
\end{tabular}

lower stability compared to MS anode in electrochemical cell. Relatively low stability of $\mathrm{Al}$ anode, as evident in OCP test, creates an environment which supports corrosion of the anode and indicates the ability of easily releasing $\mathrm{Al}^{3+}$ in to the bulk solution, compared to releasing $\mathrm{Fe}^{3+}$ ions from MS anode. Therefore, the $\mathrm{Al}$ anode shows better performance in electrocoagulation compared to MS anode (It should be noted that Fe based anodes do contribute to the electrocoagulation process). It is reported in literature that electrocoagulation with aluminum anode could achieve better ammonia nitrogen removal compared to iron anode and when the chloride ions exist in the electrolyte, the electrocoagulation exhibits better ammonia nitrogen removal through the generation of active chlorine [27].

However, the same fact would reduce the current efficiency in oxidizing TOC at $\mathrm{Al}$ anode, and therefore, the TOC removal efficiency of the $\mathrm{Al}$ anode is lower compared to the MS anode. The TOC removal is occurred mainly through electrochemical oxidation. The oxidants generated at the $\mathrm{Al}$ anode may have heavily used in corrosion (since the electrode is highly prone to corrosion as shown in OCP results) rather than contributing to oxidation [12]. Moreover, the electro-Fenton process in the cell with $\mathrm{Fe}$ base anode would have contributed to the better TOC removal at MS anode [28, 29].

About $80 \%$ reduction in TN from synthetic wastewater solution using electrochemical reactor with $\mathrm{Fe}$ cathode and a $\mathrm{Ti} / \mathrm{IrO}_{2}-\mathrm{Pt}$ anode in $3 \mathrm{~h}$ reaction time is reported [15]. Current density as of the study is reported as $20 \mathrm{~mA} / \mathrm{cm}^{2}$; however, the initial TN concentration is around $100 \mathrm{mg} / \mathrm{L}$, which is lower than that of the current study. Compared to the denitrification efficiencies obtained using groundwater, which is $99 \%$ [7], the values reported in Table 4 for TN removal are small. This can be due to few reasons. The electrolyte in this study is a complex one with several co-existing pollutants such as organic matter. Applied current is used for redox reactions, however, the efficiency is not fully utilized by the intended reaction. Part of the applied energy is utilized for reactions such as organic carbon removal. TN concentration of this study is far beyond (around $600 \mathrm{mg} / \mathrm{L}$ ) the other studies stated above (varies between 15-175 mg/L). Therefore, direct comparison of efficiencies is not fair.

Therefore, it can be concluded that, use of $\mathrm{Al}$ anode with developed $\mathrm{Cu} / \mathrm{Al}$ cathode is the best possible combination of electrodes for treating leachate, considering removal of TN from leachate. The same anode-cathode system facilitates simultaneous removal of TOC from leachate as well. In addition, it should be noted that the selected electrodes are of low cost, reducing the initial and maintenance cost of the system.

After selecting the electrodes, further investigations were carried out using Udapalatha landfill leachate. Based on Table 3 , $\mathrm{pH}$ of both landfill sites were approximately the same. Amount of ammonia-N and TN of Udapalatha leachate was about $50 \%$ lower than that of Gohagoda leachate. However, nitrate-N amount of Udapalatha leachate was about 30\% higher than that of Gohagoda leachate. TOC amount of Gohagoda leachate was about $30 \%$ higher than that of Udapalatha leachate while Nitrite-N amount of both landfill sites were under detectable level.

Udapalatha raw leachate (i.e. as received) was treated under the same experimental conditions mentioned at Table 4. TN and TOC removal efficiencies were found as $31.27 \%$ and $26.05 \%$, respectively. Irrespective of the differences mentioned about the two leachate samples, TN and TOC removal efficiencies of two landfill sites were very similar to each other. Further, ammonia-N and nitrate-N removal efficiencies were found out as $22.71 \%$ and $91.8 \%$, respectively. These results suggest that the electrochemical reactor is very efficient in denitrification. This may be due to the high activity of the cathode of the reactor in reducing nitrate and support of anode to remove nitrate through electrocoagulation. However, reactor performance in removing ammonia- $\mathrm{N}$ is not very high and thus the TN removal efficiency also not very appealing. The electrochemical removal of ammonia occurs due to the electrochemical oxidation which occurs at anode. The low activity of anode towards electrochemical oxidation would have contributed to the low ammonia removal efficiency of the reactor. Nitrite-N amount was very low and couldn't be able to detect using the spectrophotometer.

The TN removal efficiencies (which are around 30\%) reported above suggests that the electrocoagulation may not be able to remove nitrogen to a greater extent, without compromising the

Table 4. Removing Nitrogenous Compounds from Leachate Generated at Gohagoda Landfill

\begin{tabular}{cccccc}
\hline \multirow{2}{*}{ Sample } & $\begin{array}{c}\text { Current density } \\
\left(\mathbf{m A} / \mathbf{c m}^{2}\right)\end{array}$ & \multicolumn{5}{c}{ Final concentrations and removal efficiencies } \\
\cline { 3 - 6 } & 20 & TN, $\mathbf{~ m g} / \mathbf{L}$ & TOC, $\mathbf{~ m g / L}$ & TN removal efficiency, \% & TOC removal efficiency, \% \\
\hline $\mathrm{Al}$ & 20 & 389.1 & 775.7 & 32.66 & 34.01 \\
\hline $\mathrm{MS}$ & 464.9 & 654 & 19.54 & 44.36 \\
\hline
\end{tabular}

${ }^{*}$ Reaction duration $=6 \mathrm{~h}$, Batch volume $=50 \mathrm{~mL}$, Distance between electrodes $=2 \mathrm{~cm}$, Initial total nitrogen (TN) concentration $=577.8 \mathrm{mg} / \mathrm{L}$, Initial TOC content $=1,175.4 \mathrm{mg} / \mathrm{L}$ 
Table 5. Removing Nitrogenous Compounds from Diluted Leachate (generated at Udapalatha Landfill)

\begin{tabular}{|c|c|c|c|c|c|c|c|c|c|c|}
\hline \multirow{2}{*}{ Anode } & \multirow{2}{*}{$\begin{array}{c}\text { Reaction } \\
\text { duration, } \mathbf{h}\end{array}$} & \multirow{2}{*}{$\begin{array}{c}\text { Current density, } \\
\mathbf{m A} / \mathbf{c m}^{2}\end{array}$} & \multicolumn{4}{|c|}{ Final concentration, $\mathrm{mg} / \mathrm{L}$} & \multicolumn{4}{|c|}{ Removal efficiency, \% } \\
\hline & & & TN & TOC & $\mathbf{N H}_{3}-\mathbf{N}$ & $\mathrm{NO}_{3}^{-}-\mathrm{N}$ & TN & TOC & $\mathrm{NH}_{3}-\mathrm{N}$ & $\mathrm{NO}_{3}^{-}-\mathrm{N}$ \\
\hline $\mathrm{Al}$ & 6 & 50 & 38.28 & 32.88 & 37.50 & 0.2 & 38.25 & 24.74 & 27.18 & 97.53 \\
\hline $\mathrm{Al}$ & 6 & 20 & 7.05 & 29.37 & 6.48 & Undetectable & 88.63 & 32.78 & 87.42 & 100.00 \\
\hline $\mathrm{Al}$ & 12 & 20 & 7.37 & 27.74 & 6.75 & Undetectable & 88.11 & 36.51 & 86.89 & 100.00 \\
\hline & & & & & ${ }^{*}$ Batch & volume $=50 \mathrm{I}$ & Distar & betwee & lectrode & $=2 \mathrm{~cm}$ \\
\hline
\end{tabular}

energy efficiency of the system. That is, if further removal is essential, the reactions would have to be carried out for extended durations. However, such alternatives will increase the energy requirements making the technology unacceptable. Therefore, this technology would be suitable as a pre-treatment or post-treatment step in a treatment plant for treating surface leachate.

\subsubsection{Efficiency studies with diluted leachate samples}

In order to further analyze the treatment efficiency at low concentrations, Udapalatha leachate was diluted into 1:4 proportion (leachate: total volume) and investigations were continued. As a result of dilution, EC of the sample was dropped to 2.169 $\mathrm{mS}$.

Table 5 shows the results obtained using diluted leachate. As shown in Table 5, higher current densities do not have supported the removal efficiency. While optimization experiments are required to find the optimum current density, high current densities do not support removing nitrogenous compounds may be due to loss of activity of anode due to high floc formation. As shown in Table 5, at high current density, anode was covered by the flocs. This may be due to the high rate of $\mathrm{Al}^{3+}$ production at anode and lower mass transport rate. This passivation can reduce the activity of electrode and, as a result, reduce the efficiency.

With diluted leachate, around $88 \%$ removal of TN was achieved with a current density of $20 \mathrm{~mA} / \mathrm{cm}^{2}$ and $6 \mathrm{~h}$ reaction duration. Extending the reaction duration did not show any further improvement in reactor efficiency. After achieving high efficiencies in reactor, lower residual amount of pollutants may undergo mass transfer limitations and thus further improvement in efficiency may be limited. Final nitrate levels were under the detection limit of the equipment, suggesting near complete removal of nitrates from diluted leachate. As shown in Table 5, about $30 \%$ of TOC removal is achieved in the system. Dilution did not enhance the TOC removal efficiency of the system, suggesting low activity of $\mathrm{Al}$ anode in oxidation of organics and possible mass transfer limitations after dilution. The above findings suggest that the present electrochemical reactor is capable of removing nitrogenous compounds to a significantly low level from leachate, if the leachate is pre-treated.

\section{Conclusions}

Application of electrochemical technologies in removing nitrogenous compounds from landfill leachate was investigated in this research. Cathode material of the reactor was successfully developed using electroless plating technique. Laboratory developed $\mathrm{Cu} / \mathrm{Al}$ cathode showed good performance in denitrification compared to commercially available $\mathrm{Cu}$ plate electrode. Although the electrochemically active surface area of $\mathrm{Cu} / \mathrm{Al}$ electrode is lower compared to that of $\mathrm{Cu}$ plate electrode, contribution from electrocoagulation due to the presence of $\mathrm{Al}$ would have increased the efficiency.

$\mathrm{Al}$ and MS anodes were incorporated to the electrochemical cell in order to investigate the efficiency of the electrochemical reactor in removing nitrogenous compounds. Developed $\mathrm{Cu} / \mathrm{Al}$ electrode was used as the cathode material. $\mathrm{Al}$ anodes showed promising results compared to MS. Low OCP of $\mathrm{Al}$ compared to MS suggested that the $\mathrm{Al}$ is more prone to release $\mathrm{Al}^{3+}$ ions to the electrolyte and thus efficient in electrocoagulation compared to MS. It is concluded that the comparatively high efficiency of $\mathrm{Al}$ in electrocoagulation positively contributed in removing nitrate from the system and thereby increase the removal efficiency in nitrogenous compounds from leachate. In addition to removing nitrogenous compounds, Al showed moderate performances in simultaneously removing TOC from leachate, providing additional advantage.

When the leachate as received was used to test the reactor performances, high removal of nitrate-N (about 90\%) was achieved. However, the removal of ammonia-N and therefore the removal of TN were low (around 30\%). It is concluded that this phenomena can be due to the low oxidation ability of $\mathrm{Al}$ anode. However, with diluted leachate, a TN removal efficiency of about $88 \%$ was achieved. Therefore, the developed electrochemical reactor system can be used as a secondary or tertiary treatment step in a surface leachate treatment plant.

\section{Acknowledgments}

Authors acknowledge the financial support given by University 
of Peradeniya, Sri Lanka, through university research grant RG/2014/22/E and for supporting the research assistantship by WaSo-Asia Project.

\section{References}

1. Guyer JP. An introduction to sanitary landfills. Continuing Education and Development, Inc. [Internet]. New York; c2009 [Cited 201805 March 2018]. Available from: https://www. cedengineering.com/userfiles/An\%20Introduction \%20to\%20Sanitary\%20Landfills.pdf.

2. El-Salam MMA, Abu-Zuid GI. Impact of landfill leachate on the groundwater quality: A case study in Egypt. J. Adv. Res. 2015;6:579-586.

3. Raghab SM, El Meguid AMA, Hegazi HA. Treatment of leachate from municipal solid waste landfill. HBRC J. 2013;9:187-192.

4. Kristanto GA, Rialdi H, Gusniani I. Nitrogen removal from landfill leachate via ex-situ nitrification and in-situ denitrification in laboratory scale bioreactor. Procedia Eng. 2017;171:425-433.

5. Mukherjee S, Mukhopadhyay S, Hashim MA, Gupta BS. Contemporary environmental issues of landfill leachate: Assessment and remedies. Crit. Rev. Environ. Sci. Technol. 2015;45:472-590.

6. Camargo JA, Alonso A. Ecological and toxicological effects of inorganic nitrogen pollution in aquatic ecosystems: A global assessment. Environ. Int. 2006;32:831-849.

7. Abeygunawardhana $P$, Nanayakkara N, Vithanage $M$. Development and optimization of $\mathrm{Ti} / \mathrm{Cu}$ cathode and $\mathrm{Ti} / \mathrm{IrO}_{2}$ anode for electrochemical denitrification. Desalin. Water Treat. 2016;57:19025-19037.

8. Yao P. Perspectives on technology for landfill leachate treatment. Arab. J. Chem. 2017;10:S2567-S2574.

9. Ifeanyichukwu MJ. New leachate treatment methods [master's thesis]. Sweden: Lund Univ.; 2008.

10. Pathiraja GC, Jayathilaka PB, Weerakkody C, et al. Comparison study of dimensionally stable anodes for degradation of chlorpyrifos in water. Curr. Sci. 2014;107:219-226.

11. Mook WT, Chakrabarti MH, Aroua MK, et al. Removal of total ammonia nitrogen (TAN), nitrate and total organic carbon (TOC) from aquaculture wastewater using electrochemical technology: A review. Desalination 2012;285:1-13.

12. Nanayakkara KGN. Ballast water disinfection using electrochemical technologies [dissertation]. Singapore: National Univ. of Singapore; 2010.

13. Dash BP, Chaudhari S. Electrochemical denitrification of simulated groundwater. Water Res. 2005;39:4065-4072.

14. Dortsiou M, Kyriacou G. Electrochemical reduction of nitrate on bismuth cathodes. J. Electroanal. Chem. 2009;630:69-74

15. Li M, Feng C, Zhang Z, et al. Efficient electrochemical reduction of nitrate to nitrogen using $\mathrm{Ti} / \mathrm{IrO}_{2}$-Pt anode and different cathodes. Electrochim. Acta 2009;54:4600-4606.

16. Li M, Feng C, Zhang Z, et al. Optimization of process parameters for electrochemical nitrate removal using Box-Behnken design. Electrochim. Acta 2010;56:265-270.

17. Reyter D, Belanger D, Roue L. Nitrate removal by a paired electrolysis on copper and $\mathrm{Ti} / \mathrm{IrO}_{2}$ coupled electrodes-Influence of the anode/cathode surface area ratio. Water Res. 2010;44:1918-1926.

18. Genders JD, Hartsough D. Electrochemical reduction of nitrates and nitrites in alkaline nuclear waste solutions. J. Appl. Electrochem. 1996;26:1-9.

19. Peel JW, Reddy KJ, Sullivan BP, et al. Electrolytic reduction of nitrate in water. Water Res. 2003;37:2512-2519.

20. Huang YH, Zhang TC. Effects of low $\mathrm{pH}$ on nitrate reduction by iron powder. Water Res. 2004;38:2631-2642.

21. Reyter D, Belanger D, Roue L. Optimization of the cathode material for nitrate removal by a paired electrolysis process. J. Hazard. Mater. 2011;192:507-513.

22. Li L, Liu Y. Ammonia removal in electrochemical oxidation: Mechanisms and pseudo-kinetics. J. Hazard. Mater. 2009;161: 1010-1016.

23. Liu Y, Li L, Goel R. Kinetic study of electrolytic ammonia removal using $\mathrm{Ti} / \mathrm{IrO}_{2}$ as anode under different experimental conditions. J. Hazard. Mater. 2009;167:959-965.

24. Singh H, Mishra BK. Assessment of kinetics behavior of electrocoagulation process for the removal of suspended solids and metals from synthetic water. Environ. Eng. Res. 2016;22:141-148.

25. Prica M, Adamovic S, Dalmacija B, et al. The electrocoagulation/flotation study: The removal of heavy metals from the waste fountain solution. Process Saf. 2015;94:262-273.

26. Lacasa E, Canzares P, Saez C, et al. Removal of nitrates from groundwater by electrocoagulation. Chem. Eng. J. 2011;171: 1012-1017.

27. Yang L, Shen Z, Zhang Y. Influence of operating parameters on ammonia nitrogen removal from micro-polluted water by electro-coagulation-flotation with aluminum electrodes. $13^{\text {th }}$ IWA (International Water Association) specialize conference on Small Water and Wastewater Systems, Athens, Greece; 2016.

28. Jiang C, Zhang J. Progress and prospect in electro-Fenton process for wastewater treatment. J. Zhejiang Univ. Sci. A. 2007;8: 1178-1125.

29. Lin H. Removal of organic pollutants from water by electro-Fenton and electro-Fenton like processes [dissertation]. Université Paris-Est; 2015. 